\title{
Sprawozdanie z poznańskiej konferencji naukowej w 250. rocznicę konfederacji barskiej Za wiarę i wolność \\ (9-11 maja 2018 roku)
}

\section{BARBARA JUDKOWIAK}

(Uniwersytet im. Adama Mickiewicza w Poznaniu)

Spotkanie współorganizowały Instytuty Historii, Historii Sztuki i Filologii Polskiej Uniwersytetu im. Adama Mickiewicza w Poznaniu oraz Komisja Historii Sztuki Poznańskiego Towarzystwa Przyjaciół Nauk Biblioteki Raczyńskich, Biblioteka Kórnicka Polskiej Akademii Nauk i Wielkopolskie Muzeum Niepodległości. Obradom, które toczyły się Io-II maja 2018 roku w Sali Czerwonej Pałacu Działyńskich przy Starym Rynku, towarzyszyło spotkanie $\mathrm{z}$ autorką słownika biograficznego konfederatów barskich na Syberii Swietłaną Muliną z Omska, które odbyło się w Domu Literatury (Muzeum Józefa Ignacego Kraszewskiego) Biblioteki Raczyńskich 9 maja, oraz prezentacja w zabytkowej przestrzeni Pałacu Działyńskich starannie dobranych eksponatów związanych z konfederacją barską pochodzących ze zbiorów Biblioteki Kórnickiej PAN (m.in. $z$ archiwum Zaremby), Muzeum Narodowego w Poznaniu i Wielkopolskiego Muzeum Wojskowego (Oddział MNP). Wygłoszono dziewiętnaście referatów, których autorami - poza gościem z Rosji, wspomnianą Swietłaną Muliną - byli historycy, historycy sztuki i literatury z warszawskich i poznańskich środowisk uniwersyteckich oraz Polskiej Akademii Nauk, a także muzeów.

Poznańskie spotkanie naukowe wpisane zostało w perspektywę ożywionych w roku stulecia odzyskania niepodległości namysłów nad tradycją postaw i dążeń niepodległościowych, a jednocześnie w rocznicę pierwszego (na przełomie lat I767 i I768) wystąpienia w obronie polskiej niepodległości. Planowane pogłębienie refleksji o roli i miejscu Wielkopolski w przebiegu konfederacji barskiej wymagało zarysowania szerszego tła; jednocześnie zaprojektowano ogląd ogólniejszych i sięgających dalej w czasie reperkusji kulturowych konfederacji. 
Otwierające konferencję wystąpienie Krzysztofa Koehlera wprowadziło słuchaczy w ideowe inspiracje płynące z sarmackiej medytacji poetyckiej wokół pojęć wiary i wolności. W rozważaniach, których autor odwołał się do inspiracji Reinharta Kosselecka i Quentine’a Skinnera, egzemplifikacyjnie jako „jaśniejące punkty” na tle dziejów instrumentalizowania pojęcia wolności w walkach o władzę uprzywilejowane zostały idea wyrażona jeszcze w XVI wieku schematem quincunx (Stanisław Orzechowski) oraz późnosiedemnastowieczna Psalmodia polska Wespazjana Kochowskiego.

Pierwszy dzień konferencji poświęcony był charakterystyce przebiegu wydarzeń konfederackich w Wielkopolsce. Maciej Broniewski w swym referacie skupił uwage na ikonosferze Poznania czasów konfederacji, szukając ideowego oblicza miasta. Wskazał idee czytelne w zdobieniach ratusza oraz znamiona rekatolicyzacji przestrzeni i społeczeństwa miasta, które odnaleźć można w nowej świątyni karmelitów (na miejscu zborów innowierców na wzgórzu św. Wojciecha) i w programie ikonograficznym jezuickiego kościoła farnego. W tym ostatnim interesująco rysuje się paralela historii misji Polski wobec misji Kościoła i Towarzystwa Jezusowego, swoista sakralizacja historii Polski (nawiązanie do patrona fary, św. Stanisława, biskupa i męczennika).

Karol Kościelniak przedstawił historię wojska w Wielkopolsce występującego pod węzłem konfederackim (pozyskiwanie wojska komputowego, a później powoływanie własnego, któremu poświęcono szczególnie wiele starań), a także sylwetki jego bohaterów (jak Ignacy Malczewski czy Józef Zaremba) i przyczyny klęsk tej armii (związane głównie z prywatą i rozgrywkami o władzę).

Zbigniew Pilarczyk postawił pytanie: czy Poznań mógł być twierdzą konfederatów? Odpowiadając na nie, zaprezentował proponowane na planach saskich i rosyjskich miasta, a podjęte fragmentarycznie przebudowy pierścienia wałów i murów mające na celu unowocześnienie starych średniowiecznych fortyfikacji. Wskazał miejsca trudne do obrony. Niezrozumienie znaczenia rozbudowy umocnień wedle planów rosyjskich wynikało między innymi z tradycyjnego myślenia konfederatów „kawalerią”, toteż Poznań nie odegrał roli jako twierdza.

Grzegorz Glabisz zanalizował specyfikę funkcjonowania i organizacji związku na tle dotychczasowej praktyki prowincji wielkopolskiej: nieuznanie reformy sejmiku średzkiego narzuconej przez sejm Repninowski, powstanie silnej opozycji przeciw dziesięcioletniej obecności Rosjan w Wielkopolsce, równoległe funkcjonowanie i uzgadnianie ustaleń władz cywilnych i wojskowych, wyprzedzenie przez Izbę Konsyliarską (odpowiadającą działającej osiem dekad, a zlikwidowanej w I766 roku Komisji Skarbowej) o trzy miesiące powstania generalności i podejmowanie przez nią prób opanowania rozbudowanego jak nigdy dotąd związku konfederackiego. 
Innym źródłom przyjrzała się Agnieszka Bąbel - wydobyła wizerunki konfederatów wielkopolskich z tekstów ulotnych czasów barskich (niekoniecznie tych, które weszły do współtworzonej przez referentkę wielotomowej antologii literatury barskiej pod redakcją Janusza Maciejewskiego), akcentując niejednoznaczności i rozmaite chwyty, które sprawiają, że mamy do czynienia nie z konkretnymi informacjami, ale z odzwierciedleniem zmiennej (szlacheckiej) opinii publicznej. Mikołaj P. Borkowski poświęcił wystąpienie nakreśleniu szczegółowego portretu Antoniego Morawskiego, czeladnika rzeźnickiego, który został słynnym pułkownikiem konfederackim.

Swietłana Mulina z omskiego Uniwersytetu im. Fiodora Dostojewskiego od lat bada losy skazanych na zsyłkę Polaków, jako współautorka (z Anną Krich) słownika Polacy w Zachodniej Syberii. Ostatnia ćwierć XVIII - pierwsza ćwierć XIX wieku (2013), obejmuje uwagą między innymi konfederatów barskich. Uzupełnienie znanych relacji i pamiętników polskich sybiraków o archiwalne rosyjskie informacje urzędowe skłoniło autorkę do osnucia referatu o konfederatach na Syberii wokół, jak głosił tytuł wystąpienia, faktów - źródeł - mitów. Zwróciła na przykład uwagę na zdobywanie przez Polaków pozycji wśród miejscowych za sprawą znajomości języków i zachodnioeuropejskiej ogłady, prowadzenie interesów, wreszcie niejednolity stosunek do amnestii.

Dwa ostatnie wystąpienia pierwszego dnia obrad dotyczyły Jędrzeja Kitowicza. Michał Mencfel wskazał perypetie edytorskie i praktyki dziewiętnastowiecznego wydawcy pism Kitowicza o dziejach konfederacji, Edwarda Raczyńskiego, przypominając o roli cenzury „familijnej” w zniekształceniu przekazu. Barbara Judkowiak, korzystając z niedawnej edycji „trzeciego dzieła” autora Opisu obyczajów, którą jest publikacja Korespondencja i gazetki rękopiśmienne Jędrzeja Kitowicza z lat I77I-I776 śledziła etapy kształtowania się obrazu wydarzeń konfederackich u autora jako sekretarza Zaremby, po wtóre nowiniarza (autora gazetek pisanych w czasie działań wojsk i generalności), a wreszcie historiografa (Pamiętniki czyli historia polska).

Drugiego dnia obrady rozpoczął Paweł Ignaczak prezentacją materiału bardzo rozproszonego, a mianowicie grafiki czasów konfederacji barskiej, która nasuwa pytania o możliwości rozpatrywania jej jako zjawiska artystycznego i kulturowego (propaganda). Główne tematy podejmowane w warsztatach Augsburga, Frankfurtu, Brunszwiku, Monachium, Berlina i Berdyczowa to porwanie króla (przedstawiane z jego punktu widzenia!), po drugie - bitwy i po trzecie - wizerunki konfederatów (tworzące poczet bohaterów pozytywnych). Obrazy układające się w serie (numerowane), niekiedy kolorowane, operowały także słowem (umieszczanym

1 Korespondencja i gazetki rękopiśmienne Jędrzeja Kitowicza z lat 1771-1776, wyd. T. Ciesielski, S. Górzyński, F. Wolański, Warszawa 2017. 
w inskrypcji), rejestrując interpretacje obu stron konfliktu. Kolejny referat $\mathrm{z}$ historii sztuki, Jacka Kowalskiego, dotyczył możliwości interpretowania kolejnych szczegółów chorągwi konfederackiej (Muzeum Wojska Polskiego w Warszawie nr akcesyjny 205I), zwłaszcza scen zbiorowych. Tytuł wystąpienia: Matka Boska zamiast króla wskazuje ów trop (rozpatrywany na szerokim tle porównawczym schematów przedstawieniowych z tego okresu). Jarosław Łuczak pokazał na ekspozycji i omówił konfederacki ryngraf (?) czy raczej kaplerz (napierśnik i odpowiadający mu kirys na plecy) z Muzeum Wojska Polskiego (oddział Muzeum Narodowego w Poznaniu). Oryginalność tego przestrzelonego wizerunku Chrystusa Ukrzyżowanego i Najświętszej Marii Panny Niepokalanie Poczętej z konfederackim zawołaniem „Jezus Maryja” ukazana została na tle analogicznych obiektów ze zbiorów polskich.

Dopełnieniem części konferencji omawiającej świadectwa z czasów konfederacji były dwa referaty literaturoznawcze. Jacek Wójcicki dokonał analizy Wiersza po odebranej wiadomości o zupetnym ozdrowieniu Najjaśniejszego Stanistawa Augusta. $\mathrm{Z}$ rozpatrzenia zawartości i poetyki tej zachowanej w trzech egzemplarzach broszury na tle relacji i okolicznościowej poezji związanej z porwaniem króla z nurtu antykrólewskiego i polemik z replikami na nią piór prokrólewskich (Adam Naruszewicz) wyłania się tytułowa żartobliwa synteza Wójcickiego: Wiele hałasu o but... Agata Grabowska-Kuniczuk, dzieląc się doświadczeniami z warsztatu edytora „Literatury konfederacji barskiej”, wybrała konfederackie teksty „rozliczeniowe”, by zilustrować ujęte w metaforę tytułową Kłótnie matkobójców, gdy podziałem Polski w I772 roku skończyła się generalna konfederacja. Pośród nich ironiczny Aplauz dla JM Zaremby (ze zbiorów w Suchej, dziś w Archiwum Głównym Akt Dawnych) zarzut zdrady kwituje wyrokiem: „Niech ci zapłatą będzie szubienica i koło”.

W ostatniej grupie referatów, poświęconych żywotności tradycji barskiej w wiekach następnych, najpierw Mariusz Bryl pokazał, jak można czytać największy obraz olejny Artura Grottgera sprzed 1863 roku Modlitwa konfederatów barskich przed bitwa (od Bołoza Antoniewicza: pod Lanckorona), biorąc pod uwagę również źródła ikonograficzne porównawcze i zewnętrzne (informacje pisane o kontekście batalistycznym, biograficznym, ważnym dla identyfikacji postaci, ich układu etc.). Kolejny referent, Mateusz Bourkane, wydobył z powieściowej trylogii Władysława Reymonta Rok 1794 postaci konfederatów barskich, weteranów. To „stare żołnierzyska i bezdomne nieszczęśniki” - towarzysze Onufrego Zaręby, którzy ukrywają broń („co ma być użyte”, czeka na okazję). Tacy zaś jak główny bohater (bratanek Onufrego Sewer), podejmują hasło Nil desperandum i wyzwanie insurekcyjne. W ten sposób ciągłość doświadczenia historycznego i losów indywidualnych oznacza ciągłość „sprawy polskiej”, potwierdzenie znajduje więc opinia Jerzego Michalskiego, że konfederaci barscy przez wiele lat sprawują rząd dusz w Polsce. Wskazuje na to także wystąpienie Elżbiety Nowickiej poświęcone obrazom konfederacji barskiej 
w dramatach Juliusza Słowackiego z lat trzydziestych i czterdziestych XIX stulecia, od Snu srebrnego Salomei do Księdza Marka (i jego związku z Księciem Nieztomnym), służącym podkreśleniu godności wystąpienia w obronie słusznej sprawy.

Na koniec Violetta Jurkowska skupiła uwagę słuchaczy na sposobie przedstawiania ruchu barskiego w polskiej historiografii i edukacji historycznej, w której ważne miejsce przypada konfederackim bohaterom, wypełniającym pola pamięci komunikatywnej i kulturowej (wedle propozycji Aleidy i Jana Assmanów oraz Pierre'a Nory), dyskusji nad przyczynami upadku Polski (szkoła krakowska uznaje, że powodem był charakter narodowy; Melchior Wańkowicz i Stanisław Mackiewicz wskazują z kolei na twórczy rys anarchii w Polsce).

Referatom towarzyszyła żywa i obszerna dyskusja toczona wobec wiernej publiczności przez badaczy wzajemnie zainteresowanych swymi odmiennymi warsztatami i uzyskanymi wynikami (obradujących w grupie w miarę stałej, co rzadkie podczas konferencji, które nie mają charakteru wyjazdowego do ośrodka odciętego od świata). Organizatorom dało to poczucie udanego spotkania i sensowności przedsięwzięcia. Jego podsumowaniem będzie przygotowywana obecnie zbiorowa monografia zawierająca wyniki badań prezentowane podczas konferencji. 